\title{
Why Meaning in Life Matters for Societal Flourishing
}

\author{
Clay Routledge ${ }^{1 *}$ and Taylor A. FioRito ${ }^{2}$ \\ ${ }^{1}$ Department of Management and Marketing, North Dakota State University, Fargo, ND, United States, ${ }^{2}$ Department of \\ Psychology, North Dakota State University, Fargo, ND, United States
}

Keywords: meaning, flourishing, motivation, economics, prosocial behavior, self-regulation

\section{INTRODUCTION}

Meaning in life reflects the feeling that one's existence has significance, purpose, and coherence (see Heintzelman and King, 2014). A growing body of research identifies meaning in life as a fundamental human need that strongly influences both psychological and physical well-being (see Vail and Routledge, 2020). Individuals who perceive their lives as full of meaning live longer, healthier, and happier lives than those less inclined to view their lives as meaningful. Despite the growing recognition that meaning in life is vital for humans, scholars have largely ignored how meaning influences broader societal flourishing. We propose that meaning has important social and economic implications, particularly when societies are facing major existential threats such as the current COVID-19 pandemic. More specifically, we argue that meaning functions as

OPEN ACCESS

Edited by:

Dimitri Van Der Linden, Erasmus University

Rotterdam, Netherlands

Reviewed by:

Tatjana Schnell,

University of Innsbruck, Austria

Daryl R. Van Tongeren,

Hope College, United States

*Correspondence:

Clay Routledge

clay.routledge@ndsu.edu

Specialty section:

This article was submitted to Personality and Social Psychology, a section of the journal Frontiers in Psychology

Received: 01 September 2020 Accepted: 16 December 2020 Published: 14 January 2021

Citation:

Routledge C and FioRito TA (2021)

Why Meaning in Life Matters for Societal Flourishing.

Front. Psychol. 11:601899.

doi: 10.3389/fpsyg.2020.601899 a self-regulatory and motivational intrapsychic resource that orients people toward the types of cognitions and behaviors that build and sustain healthy communities and societies.

\section{MEANING PROMOTES PSYCHOLOGICAL AND PHYSICAL HEALTH}

Scholars have long recognized that meaning in life is an important psychological need. The more people feel meaningful, the more they experience overall positive psychological well-being (e.g., Steger and Frazier, 2005). Moreover, meaning reduces the risk for depression (e.g., Disabato et al., 2017), addiction (e.g., Kinnier et al., 1994), and suicide (e.g., Edwards and Holden, 2001). Meaning is also positively associated with physical health and longevity (e.g., Czekierda et al., 2017).

\section{A MOTIVATIONAL VIEW OF MEANING}

Understanding why meaning matters so much for health and well-being paves the way for a broader analysis of existential health and the role it plays in societal flourishing. Meaning positively contributes to psychological and physical health because of its motivational and self-regulatory nature (see Hooker et al., 2018; Routledge, 2018). For example, meaning in life, but not well-being indicators such as positive affect or optimism, positively predicts physical activity (Hooker and Masters, 2016) and when people are thinking about what gives their lives meaning, they are more likely to engage in physical exercise and to exercise for longer intervals, even if they were previously physically inactive (Hooker and Masters, 2018).

More broadly, meaning drives goal pursuit (see Routledge, 2018). For instance, when individuals bring to mind and reflect on meaningful life memories, they subsequently report greater perceptions of meaning and motivation to pursue goals, and this motivational effect cannot be attributed to positive affect (Sedikides and Wildschut, 2018). Findings such as these reveal that when people are focused on what gives their lives meaning, they are generally more agentic and 
inspired. These and related findings (see Steger et al., 2006) also highlight that meaning isn't synonymous with other well-being indicators.

Research identifying meaning as a coping resource further reveals its motivational nature (see Park, 2010). For example, when people face mental health challenges, meaning in life may play a vital role in treatment success by motivating people to be compliant and actively engaged in the treatment process. Indeed, people with greater perceptions of meaning respond more positively to psychotherapy (Debats, 1996). Life often involves experiences of uncertainty, stress, sadness, and loss. Eventually, we all lose loved ones and must face death ourselves. Critically, meaning is a vital psychological resource for coping with these challenges (Park and Folkman, 1997). Those who are able to respond to tragedy and loss in ways that affirm meaning are better able to move forward with their lives in productive ways and to be at peace with their own mortality (see Routledge and Vess, 2018). When people believe their lives matter, they have a reason to regulate their behavior in ways that helps keep them alive and thriving.

\section{MEANING AS A CRITICAL INGREDIENT OF SOCIETAL FLOURISHING}

The well-being of any society is directly linked to the wellbeing of the individuals living in it. Thus, the fact that meaning in life supports individual flourishing provides critical evidence that it also promotes societal flourishing. However, the positive influence of meaning on societal well-being is more than the sum of individuals regulating their own behavior in ways that help them stay healthy and pursue self-focused goals. Meaning in life and the agency it generates has important implications for social and economic health, which are two critical ingredients of societal flourishing.

Meaning promotes social and community engagement. Numerous studies have identified social bonds as a primary source of meaning in life. For example, when asked to detail in writing what gives their lives meaning, the most frequently reported source of meaning is close relationships (Nelson et al., 2019). However, research also indicates that meaning promotes the pursuit of social connections. For example, Stavrova and Luhmann (2016) observed that meaning in life positively predicted the extent to which individuals felt connected to their community, family, friends, and spouse/partner 10 years later. In a second study, these researchers found even stronger evidence for a social motivational function of meaning; higher levels of meaning predicted a greater likelihood of future participation in voluntary associations, and, among single people, a greater likelihood of getting married. Such findings are consistent with laboratory research showing that when people reflect on personally meaningful past social experiences, they become more motivated to pursue social goals and more confident that they can overcome problems in their relationships (Abeyta et al., 2015).

Moreover, the more individuals report a desire to live a meaningful life, the more they engage in prosocial behavior such as volunteering and charitable giving (FioRito et al., in press). This suggests that the need for meaning orients people toward helping others and supporting the social organizations that they believe improve society.

Meaning in life may also promote societal flourishing at the economic level. For example, a sense of purpose in life predicts gains in household income and net worth over time (Hill et al., 2016). Since meaning promotes self-control and goal-directed behavior generally, it likely supports the types of economic decision-making and work-related goals that lead to greater financial security. Greater financial security is key to the economic health of communities and the global economy. And individuals are better positioned to support other important features of community life (e.g., the arts) and to help those in need with charitable giving when they are able to meet their own financial needs.

\section{USING MEANING TO OVERCOME MAJOR SOCIETAL THREATS AND CHALLENGES}

Since meaning in life is a resource the helps people cope with stress, uncertainty, anxiety, and trauma it may also play a vital role in helping communities and the broader society face collective threats and challenges. Recent studies, for instance, found that higher meaning in life is associated with lower levels of anxiety and COVID-19 stress (Trzebinski et al., 2020) and lower levels of mental distress among those facing pandemicrelated stress (Schnell and Krampe, 2020). In order to successfully respond to and recover from collective threats such as pandemics, economic recessions, and natural disasters, humans need to possess the psychological fortitude that not only helps them manage their personal anxieties, but that also drives them to want to positively contribute to the world around them.

\section{TOWARD A MORE OUTWARD FOCUSED EXISTENTIAL PSYCHOLOGY}

Much of the research in existential psychology has focused on how meaning contributes to individual health and well-being and has ignored many of the ways that meaning might orient people outward. In the current analysis, by focusing on the self-regulatory and motivational functions meaning serves and connecting those functions to outcomes beyond the individual, we hope to inspire more research directed toward exploring the vital role meaning may play in promoting societal flourishing. We propose that when people view their lives as meaningful, they are better positioned and more motivated to take care of themselves and make valuable contributions to their families, communities, nation, and the world.

\section{AUTHOR CONTRIBUTIONS}

All authors listed have made a substantial, direct and intellectual contribution to the work, and approved it for publication. 


\section{REFERENCES}

Abeyta, A. A., Routledge, C., and Juhl, J. (2015). Looking back to move forward: nostalgia as a psychological resource for promoting relationship goals and overcoming relationship challenges. J. Pers. Soc. Psychol. 109, 1029-1044. doi: $10.1037 /$ pspi0000036

Czekierda, K., Banik, A., Park, C. L., and Luszczynska, A. (2017). Meaning in life and physical health: systematic review and meta-analysis. Health Psychol. Rev. 11, 387-418. doi: 10.1080/17437199.2017.1327325

Debats, D. L. (1996). Meaning in life: clinical relevance and predictive power. $\mathrm{Br}$. J. Clin. Psychol. 35, 503-516. doi: 10.1111/j.2044-8260.1996.tb01207.x

Disabato, D. J., Kashdan, T. B., Short, J. L., and Jarden, A. (2017). What predicts positive life events that influence the course of depression? A longitudinal examination of gratitude and meaning in life. Cogn. Ther. Res. 41, 444-458. doi: 10.1007/s10608-016-9785-x

Edwards, M. J., and Holden, R. R. (2001). Coping, meaning in life, and suicidal manifestations: examining gender differences. J. Clin. Psychol. 57, 1517-1534. doi: $10.1002 /$ jclp. 1114

FioRito, T. A., Routledge, C., and Jackson, J. (in press). Meaning-motivated community action: the need for meaning and prosocial goals and behavior. Pers. Individ. Diff.

Heintzelman, S., and King, L. A. (2014). Life is pretty meaningful. Am. Psychol. 69, 561-574. doi: 10.1037/a0035049

Hill, P. L., Turiano, N. A., Mroczek, D. K., Burrow, A. L. (2016). The value of a purposeful life: sense of purpose predicts greater income and net worth. J. Res. Pers. 65, 38-42. doi: 10.1016/j.jrp.2016.07.003

Hooker, S. A., and Masters, K. S. (2016). Purpose in life is associated with physical activity measured by accelerometer. J. Health Psychol. 21, 962-971. doi: $10.1177 / 1359105314542822$

Hooker, S. A., and Masters, K. S. (2018). Daily meaning salience and physical activity in previously inactive exercise initiates. Health Psychol. 37, 344-354. doi: $10.1037 /$ hea0000599

Hooker, S. A., Masters, K. S., and Park, C. L. (2018). A meaningful life is a healthy life: a conceptual model linking meaning and meaning salience to health. Rev. General Psychol. 22, 11-24. doi: 10.1037/gpr0000115

Kinnier, R. T., Metha, A. T., Keim, J. S., Okey, J. L., Adler-Tabia, R. L., Berry, M. A., et al. (1994). Depression, meaninglessness, and substance abuse in 'normal' and hospitalized adolescents. J. Alcohol Drug Educ. 39, 101-111.

Nelson, T. A., Abeyta, A. A., and Routledge, C. (2019). What makes life meaningful for theists and atheists? Psychol. Relig. Spirituality. doi: 10.1037/rel0000282. [Epub ahead of print].
Park, C. L. (2010). Making sense of the meaning literature: an integrative review of meaning making and its effects on adjustment to stressful life events. Psychol. Bull. 136, 257-301. doi: 10.1037/a0018301

Park, C. L., and Folkman, S. (1997). Meaning in the context of stress and coping. Rev. General Psychol. 1, 115-144. doi: 10.1037/1089-2680.1.2.115

Routledge, C. (2018). Supernatural: Death, Meaning, and the Power of the Invisible World. New York, NY: Oxford University Press.

Routledge, C., and Vess, M. (2018). The Handbook of Terror Management Theory. New York, NY: Academic Press.

Schnell, T., and Krampe, H. (2020). Meaning in life and self-control buffer stress in times of COVID-19: moderating and mediating effects with regard to mental distress. Front. Psychiatry 11:983. doi: 10.3389/fpsyt.2020. 582352

Sedikides, C., and Wildschut, T. (2018). Finding meaning in nostalgia. Rev. General Psychol. 22, 48-961. doi: 10.1037/gpr0000109

Stavrova, O., and Luhmann, M. (2016). Social connectedness as a source and consequence of meaning in life. J. Positive Psychol. 11, 470-479. doi: $10.1080 / 17439760.2015 .1117127$

Steger, M. F., and Frazier, P. (2005). Meaning in life: one chain from religiousness to well-being. J. Couns. Psychol. 52, 574-582. doi: 10.1037/0022-0167.52. 4.574

Steger, M. F., Frazier, P., Oishi, S., and Kaler, M. (2006). The meaning in life questionnaire: assessing the presence of and search for meaning in life. J. Couns. Psychol. 53, 80-93. doi: 10.1037/0022-0167.53.1.80

Trzebinski, J., Cabanski, M., and Czarnecka, J. Z. (2020). Reaction to the COVID-19 pandemic: the influence of meaning in life, life satisfaction, and assumptions on world orderliness and positivity. J. Loss Trauma 25, 544-557. doi: 10.1080/15325024.2020.1765098

Vail, K., and Routledge, C. (2020). The Science of Religion, Spirituality, and Existentialism. New York, NY: Elsevier.

Conflict of Interest: The authors declare that the research was conducted in the absence of any commercial or financial relationships that could be construed as a potential conflict of interest.

Copyright (c) 2021 Routledge and FioRito. This is an open-access article distributed under the terms of the Creative Commons Attribution License (CC BY). The use, distribution or reproduction in other forums is permitted, provided the original author(s) and the copyright owner(s) are credited and that the original publication in this journal is cited, in accordance with accepted academic practice. No use, distribution or reproduction is permitted which does not comply with these terms. 